\title{
PENGARUH SCIENCE COMIC TERHADAP HASIL BELAJAR SISWA
}

\author{
Desi Kurniawati ${ }^{1}$, Ismul Mauludin Al Habib ${ }^{2}$, Dwi Sucianingtyas Sukamto ${ }^{3}$ \\ IKIP PGRI Jember ${ }^{1,2,3}$ \\ D-kurnia201@gmail.com ${ }^{1}$
}

\begin{abstract}
ABSTRAK
Penelitian ini bertujuan untuk mengetahui pengaruh science comic terhadap hasil belajar siswa kelas VIII pada materi sistem peredaran darah manusia di SMP Negeri 7 Jember. Desain penelitian ini berupa Nonequivalent Control Group Design. Teknik pengambilan sampel dalam penelitian ini yakni teknik purposive sampling. Sampel yang dipilih peneliti yaitu kelas kelas VIII D sebagai kelas ekperimen berjumlah 37 siswa dan kelas VIII E sebagai kelas kontrol berjumlah 35 siswa. Instrumen penelitian ini berupa tes subjektif dengan menggunakan 10 butir soal valid. Teknik analisa data kelas eksperimen dan kelas kontrol menggunakan uji statistik nonparametrik yaitu uji Wilcoxon yang dihitung dengan aplikasi SPSS 24, diperoleh signifikansi sebesar 0,00 lebih kecil dari 0,05 . Hasil rata-rata nilai posttest kelas eksperimen menunjukkan angka sebesar 85,37 dari 37 siswa sedangkan pada kelas kontrol sebesar 69 dari 35 siswa. Hasil nilai $N$-gain diperoleh rata-rata yakni 0,77 dari 37 siswa pada kelas eksperimen dan rata-rata 0,69 dari 35 siswa pada kelas kontrol. Dari hasil penelitian dapat disimpulkan bahwa science comic berpengaruh terhadap hasil belajar siswa kelas VIII pada materi sistem peredaran darah manusia di SMP Negeri 7 Jember.
\end{abstract}

Kata Kunci: science comic, hasil belajar, sistem peredaran darah

\begin{abstract}
This research aims to determine the content of comic science on the learning outcomes of class VIII students on human circulatory system material in SMP Negeri 7 Jember. The design of this study is Nonequivalent Control Group Design. The sampling technique in this research was purposive sampling technique. The sample chosen by the researcher was class VIII D as the experimental class, 37 students and class VIII E as the physical control class of 35 students. The instrument of this research is a test using 10 valid questions. The technique of analyzing the experimental and class classes using non-parametric statistical tests, namely the Wilcoxon test which is calculated by the SPSS 24 application, obtained a significance of 0.00 less than 0.05. The average score of post-test in experimental class was 85.37 out of 37 students while in the control class was 69 out of 35 students. The average N-gain results was 0.77 from 37 students in the experimental class and in the control class was 0.69 from 35 students. From the results of the study, it can be concluded that science comic influences the learning outcomes of eighth grade students on human circulatory system material in SMP Negeri 7 Jember.
\end{abstract}

Keywords: knowledge comics, learning outcomes, circulatory system 


\section{PENDAHULUAN}

Kegiatan belajar mengajar tidak terlepas dari sumber belajar dan media pembelajaran. Ilmu pengetahuan dan teknologi yang sedang berkembang mendorong mutu pendidikan dan menciptakan media pembelajaran yang lebih kreatif dan inofatif. Seorang pendidik untuk mencapai tujuan pembelajaran harus terlebih dahulu mengetahui bahan ajar yang menarik untuk dibekalkan pada peserta didik. Pendidik juga dituntut mampu menciptakan metode mengajar dan media pembelajaran yang kreatif dan inovatif sebagai penilaian untuk menentukan taraf tercapainya tujuan pembelajaran (Sudjana \& Rivai, 2015).

Proses belajar mengajar di Indonesia sedang melaksanakan dua macam kurikulum yang berlaku yakni Kurikulum Tingkat Satuan Pendidikan (KTSP) 2006 dan Kurikulum 2013 (K13). Kurikulum Tingkat Satuan Pendidikan (KTSP) 2006 mengacu pada delapan standar nasional pendidikan yakni standar isi, standar proses, standar kompetensi lulusan, standar pendidik dan tenaga kependidikan, standar sarana dan prasarana, standar pengelolaan, standar pembiayaan dan standar penilaian pendidikan yang telah diatur oleh Badan Standar Nasional Pendidikan (BSNP). Kurikulum 2013 diciptakan sebagai bentuk lanjutan dan penyempurnaan dari Kurikulum Tingkat Satuan Pendidikan (KTSP) 2006 untuk mencapai delapan standar nasional pendidikan (Zaini, 2015).

Salah satu pelaksana dari kedua kurikulum tersebut berada di kota Jember. SMP Negeri 7 Jember memberlakukan Kurikulum Tingkat Satuan Pendidikan (KTSP) 2006 pada kelas VIII dan kelas IX, sedangkan pada kelas VII pada tahun ajaran baru 2017/2018 sudah diberlakukan Kurikulum 2013 (K13). Kurikulum Tingkat Satuan Pendidikan merupakan penyempurnaan dari kurikulum sebelumnya yang mana pengembangan kurikulumnya sesuai dengan satuan pendidikan, potensi sekolah atau daerah, karakteristik peserta didik dan tentu serta kebutuhan masyarakat setempat (Rohman, 2015). Kurikulum Tingkat Satuan Pendidikan (KTSP) 2006 masih diterapkan di SMP Negeri 7 Jember karena sesuai dengan potensi sekolah dan karakteristik dari peserta didik.

Kurikulum Tingkat Satuan Pendidikan (KTSP) 2006 mengaplikasikan proses pembelajaran terpadu. Seperti pelajaran IPA terpadu yang mencakup ilmu biologi, kimia dan fisika. Dalam proses pembelajaran IPA terpadu yang erat kaitannya dengan gejala alam dan ilmu kebendaan yang telah teruji kebenarannya, sehingga membutuhkan tingkat pengajaran yang sistematis untuk mengembangkan pengamatan di dalamnya. IPA terpadu merupakan mata pelajaran yang memiliki unsur - unsur konseptu al yang mempengaruhi pengalaman belajar peserta didik. Oleh karena itu, dibutuhkan bahan ajar atau media yang dapat mengusung minat dan memperoleh ketuntasan hasil belajar dalam mempelajari IPA terpadu (Zain, 2013).

Permendikbud No. 58 Tahun 2013 menjelaskan bahwa proses pembelajaran saat ini harus berpusat pada peserta didik dan guru hanya menjadi fasilitator dan bukan satu-satunya sumber belajar bagi peserta didik. Peserta didik 
harus lebih aktif dalam mencari sumber belajar lain. Peserta didik yang aktif tentunya harus didukung oleh beberapa faktor baik faktor dari dalam dan faktor dari luar. Faktor dari dalam salah satunya adalah minat baca yang tinggi karena sangat sulit memahami sumber belajar kalau minat baca peserta didik rendah sedangkan faktor dari luar salah satunya tersedianya bahan ajar yang menarik dan layak bagi peserta didik sehingga mereka bisa membaca dalam kondisi yang senang dan santai (Wahab, 2016).

Berdasarkan hasil observasi awal pada tanggal 22 Juli 2017 yang dilakukan peneliti di SMP Negeri 7 Jember, bahan ajar peserta didik yang sering dijumpai di SMP Negeri 7 Jember yakni LKS dan buku paket BSE terpadu dari pemerintah yang minim gambar dan kurang menarik. Pelajaran IPA terpadu khususnya kelas VIII yang begitu sistematis membuat isi dari bahan ajar terlalu runtun dan terkesan penuh dengan teori. Hasil wawancara dari observasi awal terhadap guru IPA kelas VIII diperoleh bahwa materi dalam pembelajaran IPA khususnya pada sistem peredaran darah pada manusia yang ada dalam LKS dan buku paket BSE kurang memberikan gambaran yang lengkap dan jelas. Materi IPA terlalu bersifat abstrak dan rumit dipelajari sehingga siswa membutuhkan bahan ajar atau media yang menarik agar siswa menyerap informasi pembelajaran yang lebih baik dan meningkatkan hasil belajar.

Proses pembelajaran yang dilakukan oleh guru IPA pada materi sistem peredaran darah manusia sudah menggunakan model pembelajaran namun siswa hanya paham materi tetapi tidak menarik minat belajar, hal inilah yang membuat hasil belajar siswa pada nilai Ulangan Harian (UH) sistem peredaran darah manusia berada dibawah KKM (Kriteria Ketuntasan Minimum) yang berlaku di sekolah pada mata pelajaran IPA yakni 75. Presentase Ketuntasan Ulangan Harian (UH) pada materi sistem peredaran darah manusia di kelas VIII SMP Negeri 7 Jember tahun ajaran 2016/2017 berkisar 45\% sampai 70\%. Hasil wawancara dari observasi awal terhadap siswa khususnya kelas VIII SMP Negeri 7 Jember diperoleh bahwa peserta didik cenderung tidak menyukai buku teks apalagi tidak disertai gambar dan ilustrasi yang menarik serta peserta didik kurang meminati bahan ajar yang digunakan oleh sekolah dengan alasan materi yang sulit disajikan kurang informatif dan komunikatif. Termasuk pada materi sistem peredaran darah manusia dengan materi yang terkesan rumit dimengerti.

Menurut Daryanto (2015) dalam bukunya mengatakan bahwa secara empirik siswa cenderung menyukai buku bergambar, penuh dengan warna, dan divisualisasikan dalam bentuk realistis atau kartun. Apabila minat peserta didik kurang, maka motivasi peserta didik untuk belajar IPA juga berkurang sehingga akan berdampak pada hasil belajar. Salah satu cara untuk mengatasi hal tersebut, peneliti membuat bahan ajar berbentuk science comic atau komik sains khususnya pada materi sistem peredaran darah manusia sebagai media pembelajaran. Dalam bukunya, Sudjana dan Rivai (2015) mendefinisikan komik sebagai suatu bentuk kartun yang mengungkapkan karakter dan memerankan suatu cerita dalam urutan 
yang erat dihubungkan dengan gambar dan dirancang untuk memberikan hiburan kepada pembaca.

Istilah komik tidak asing lagi bagi peserta didik dan tenaga pendidik. Namun di SMP Negeri 7 Jember, Pendidik atau guru belum menerapkan bahan ajar atau media berbentuk science comic atau komik sains. Pendidik atau guru IPA terpadu di SMP Negeri 7 Jember khususnya kelas VIII sejauh ini sudah menerapkan metode dan media pembelajaran yang selalu berganti agar pembelajaran terkesan tidak monoton. namun kebanyakan dari peserta didik mengerjakan soal - soal ditengah pelajaran te rlalu fokus pada buku ajar yang ada dan terkesan mengutip setiap jawaban yang ada pada materi di buku ajar. Hal inilah yang membuat hasil bejalar peserta didik kelas VIII masih tidak ada peningkatan.

Penelitian sebelumnya tentang penggunaan komik dalam pembelajaran IPA dilakukan oleh Purnama, et al (2015) dengan judul penggunaan media komik digital dan gambar pengaruhnya terhadap prestasi belajar IPA dan menunjukkan keberhasilan dengan peroleh rata- hasil belajar dengan media komik digital sebesar 80,67 sedangkan rata-rata menggunakan media gambar sebesar 66,56. Penelitian tersebut terbukti bahwa dengan penggunaan komik sebagai media pembelajaran IPA berpengaruh terhadap hasil belajar siswa. Dari beberapa referensi diatas, peneliti tertarik melakukan penelitian dengan menggunakan bahan ajar inovatif sebagai media pembelajaran IPA di salah satu materi bersifat abstrak yaitu dengan SK (Standar Kompetensi) memahami berbagai sistem kehidupan manusia dan KD (Kompetensi Dasar) mendiskripsikan sistem peredaran darah pada manusia dan hubungannya dengan kesehatan.

\section{METODE PENELITIAN}

Jenis Penelitian yang digunakan oleh peneliti adalah penelitian kuantitatif dengan metode penelitian ekperimen semu (quasy experiment). Menurut Sugiyono (2016) metode ekperimen semu (quasy experiment) digunakan karena adanya kelompok kontrol tetapi tidak dapat berfungsi mengontrol variabel - variabel luar yang mempengaruhi pelaksanaan eksperimen. Desain penelitian berupa Nonequivalent Control Group Design yang bertujuan untuk mengetahui perbedaan peningkatan hasil belajar siswa yang menggunakan science comic sebagai media pembelajaran dan siswa yang tidak menggunakan science comic dalam pembelajaran. Dengan demikian dilakukan beberapa tes tertulis yang terdiri atas pretest dan posttest untuk kelas eksperimen dan kelas kontrol. Populasi dalam penelitian ini adalah semua siswa kelas VIII SMP Negeri 7 Jember tahun ajaran 2017/2018 yang terdiri dari sembilan kelas.

Teknik pengambilan sampel dalam penelitian ini yakni teknik purposive sampling. Teknik ini mengambil sampel sumber data dengan pertimbangan atau kriteria tertentu (Suharso, 2012). Pengambilan sampel dengan pertimbangan atau kriteria tertentu yakni sampel yang dipilih karena hasil belajar IPA Terpadu dua kelas VIII terendah di SMP Negeri 7 Jember peneliti memilih kelas VIII D sebagai 
kelas ekperimen dan kelas VIII E sebagai kelas kontrol.

Teknik pengumpulan data melalui metode tes, observasi, dan wawancara. Metode tes ini digunakan untuk mengukur hasil belajar siswa pada materi sistem peredaran darah manusia selama proses pembelajaran baik pada kelas ekperimen atau kelas kontrol. Tes yang digunakan yaitu tes subjektif tertulis berbentuk uraian yang dijadikan sebagai soal atau instrument pretest dan posttest. Uji coba soal dilakukan untuk mendapat data butir soal yang valid dan reliabel dengan menguji ke 26 siswa yang pernah menempuh materi sistem peredaran darah. Butir soal di uji validitas dan reliabilitas menggunakan uji statistik aplikasi program SPSS 24. Metode observasi digunakan untuk mengamati pengaruh proses pelaksanaan pembelajaran dengan science comic pada kelas eksperimen dan kelas kontrol yang sesuai dengan indikator pada RPP (Rencana Pelaksanaan Pembelajaran) sistem peredaran darah manusia.

Wawancara digunakan untuk mendapat data sebanyak-banyaknya dengan cara berhadapan langsung maupun tidak langsung sehingga dapat memberikan informasi kepada penulis (Nisa, 2014). Dalam penelitian ini, wawancara dilakukan kepada guru IPA di SMP Negeri 7 Jember tujuannya untuk mengetahui nilai hasil belajar siswa pada observasi awal serta untuk memperoleh data terkait pengaruh penggunaan science comic pada materi sistem peredaran darah manusia kepada siswa dalam pembelajaran. Selanjutnya uji hipotesis statistik yang bertujuan untuk mengetahui pengaruh science comic terhadap hasil belajar siswa kelas VIII pada materi sistem peredaran darah dengan signifikasi hasil uji > 0,05 maka $\mathrm{H} 0$ diterima, dan jika signifikasi < 0,05 maka H0 ditolak.

\section{HASIL PENELITIAN}

Hasil penelitian disajikan dalam bentuk data berupa hasil Pretest, posttest, uji normalitas, uji homogenitas, $N$-gain, dan uji hipotesis statistik dengan menggunakan aplikasi program SPSS 24. Data hasil pretest dari kelas eksperimen dan kelas kontrol dapat dilihat pada tabel berikut:

Tabel 1. Data Hasil Pretest Kelas Eksperimen dan Kelas Kontrol

\begin{tabular}{ccc}
\hline Data & $\begin{array}{c}\text { Kelas } \\
\text { Eksperimen }\end{array}$ & $\begin{array}{c}\text { Kelas } \\
\text { Kontrol }\end{array}$ \\
\hline Nilai Tertinggi & 75 & 64 \\
\hline Nilai Terendah & 22 & 22 \\
\hline Rata - Rata & 40,48 & 42,57 \\
\hline Jumlah siswa & 37 & 35 \\
\hline
\end{tabular}

Hasil posttest dari kelas eksperimen dan kelas kontrol dapat dilihat pada tabel berikut: 
Tabel 2. Data Hasil Posttest Kelas Eksperimen dan Kelas Kontrol

\begin{tabular}{ccc}
\hline Data & $\begin{array}{c}\text { Kelas } \\
\text { Eksperimen }\end{array}$ & $\begin{array}{c}\text { Kelas } \\
\text { Kontrol }\end{array}$ \\
\hline Nilai Tertinggi & 100 & 85 \\
Nilai Terendah & 75 & 42 \\
Rata- Rata & 85,37 & 69 \\
Jumlah siswa & 37 & 35 \\
\hline
\end{tabular}

Hasil $\mathrm{N}$-gain dari kategorisasi perolehan data kelas eksperimen dan kelas kontrol dapat dilihat pada tabel berikut:

Tabel 3. Kategorisasi $N$-Gain Kelas Eksperimen dan Kontrol

\begin{tabular}{lcc}
\hline Kategorisasi & $\begin{array}{c}\text { Eksperimen } \\
\text { Frekuensi }\end{array}$ & $\begin{array}{c}\text { Frekuensi } \\
\text { Kontrol }\end{array}$ \\
\hline Tinggi & 23 & 18 \\
\hline Sedang & 14 & 16 \\
\hline Rendah & 0 & 1 \\
\hline Jumlah Siswa & 37 & 35 \\
\hline Rata-rata & 0,77 & 0,69 \\
\hline Kategori & Tinggi & Sedang \\
\hline
\end{tabular}

\section{PEMBAHASAN}

Dari tabel 1 dapat dilihat bahwa nilai pretest tertinggi dari kelas eksperimen yaitu 75 dan kelas kontrol yaitu 64, sedangkan nilai pretest terendah dari kelas eksperimen yaitu 22 dan kelas kontrol yaitu 22. Rata-rata pretest kelas eksperimen yaitu 40,48 dan dari kelas kontrol yaitu 42,57. Data diatas menunjukkan bahwa kemampuan awal siswa pada rata-rata kelas eksperimen maupun kelas kontrol tidak berbeda jauh.

Tabel 2 menunjukan bahwa rata-rata posttest kelas eksperimen lebih tinggi yaitu 85,37 dibandingkan pada kelas kontrol yaitu Nilai posttest tertinggi pada kelas eksperimen yaitu 100 dan pada kelas kontrol yaitu 85, sedangkan nilai posttest terendah pada kelas eksperimen yaitu 75 dan pada kelas kontrol yaitu 42 . Perbedaan nilai posttest tersebut menunjukkan penggunaan science comic pada pembelajaran di kelas eksperimen dapat mempengaruhi perolehan nilai yang lebih tinggi di banding dengan kelas kontrol yang tidak menggunakan science comic pada pembelajaran.

Dari hasil $N$-gain pada kelas eksperimen terlihat bahwa siswa yang mempunyai kategori tinggi sebanyak 23 siswa, kategori sedang sebanyak 14 siswa, dan pada kategori rendah sebanyak 0 siswa. Sedangkan $\mathrm{N}$-gain dari kelas kontrol terlihat bahwa siswa yang mempunyai kategori tinggi sebanyak 18 siswa, 
kategori sedang sebanyak 16 siswa, dan pada kategori rendah sebanyak 1 siswa. Berdasarkan kategori pada masing-masing kelas terlihat perolehan hasil $\mathrm{N}$-gain pada kelas eksperimen lebih tinggi dari pada kelas kontrol yakni sebesar 0,77 dan pada kelas kontrol diperoleh kategori sedang yakni 0,66. Hal ini memperlihatkan pencapaian nilai yang lebih baik pada kelas eksperimen bila dibandingkan dengan kelas kontrol setelah berlangsungnya pembelajaran menggunakan media science comic pada materi sistem peredaran darah manusia.

Hasil nilai pretest kelas eksperimen yang memiliki rata-rata 40,48 dari 37 siswa dan kelas kontrol yaitu 42,57 dari 35 siswa hal ini memberi kesimpulan bahwa kemampuan awal yang dimiliki oleh siswa kelas eksperimen sebelum diberi perlakuan dan kelas kontrol sama. Hal ini dikarenakan penerimaan pengalaman belajar siswa relatif sama dan kurang memotivasi faktor kemampuan yang dimiliki oleh setiap siswa. Pengalaman belajar akan mempengaruhi hasil belajar siswa dan diperlukan inovasi baru untuk mendukung faktor kemampuan yang dimiliki siswa sehingga hasil belajar dicapai dengan baik (Kinasih, 2011).

Hasil posttest kelas eksperimen menunjukkan rata-rata sebesar 85,37 dari 37 siswa sedangkan pada kelas kontrol sebesar 69 dari 35 siswa. Pada hasil posttest ini membuktikan bahwa ada pengaruh yang tinggi atas science comic dalam pembelajaran. Data $N$ - gain kelas eksperimen menunjukkan kategori tinggi yakni 0,77 sedangkan pada kelas kontrol kategori sedang dengan nilai 0,69.

Data yang diperoleh dari uji hipotesis statistik hasil posttest kelas eksperimen maupun kelas kontrol menunjukkan hasil signifikansi sebesar 0,640 dan data dari kelas kontrol menunjukkan hasil signifikansi sebesar 0,383 sehingga menunjukkan bahwa signifikansi lebih dari > 0,05 sehingga data dari kelas eksperimen dan kelas kontrol berdistribusi homogen. Sedangkan hasil uji normalitas data kelas eksperimen dan kelas kontrol berdistribusi tidak normal dengan abjad $\mathrm{C}$ yang dikarenakan data hasil kelas eksperimen dan kelas kontrol terlalu tidak merata dan terdapat nilai yang jauh dari garis tengah sehingga data yang tidak normal diganti dengan uji nonparametrik dengan uji wilcoxon dimana hasil uji menunjukkan hasil signifikansi 0,00 atau $<0,05$ sehingga H0 ditolak dan Ztabel < Zhitung (Sujarweni, 2015) diperoleh 5,080 (tanda - tidak relevan, karena hanya menunjukkan arah) maka H0 juga ditolak. Sehingga H1 yang diterima atau science comic efektif dapat meningkatkan hasil belajar siswa kelas VIII pada materi sistem peredaran

Bahan ajar yang menarik dijadikan sebuah media pembelajaran seperti science comic berfungsi sebagai alat penyalur informasi bagi siswa. Hal ini didukung oleh Emda (2011) dalam penelitiannya yang mengatakan bahwa seorang guru atau pendidik harus mampu memilih media yang sesuai konsep yang akan disampaikan dan dapat menunjang keberhasilan proses belajar mengajar. Pemilihan media yang tepat dalam alat bantu pengajaran akan menumbuhkan minat belajar siswa dan menumbuhkan pengalaman belajarnya sendiri (Silalahi, 2015). 
Sifat komik yang mudah dan menarik untuk dibaca membuat minat baca serta kemampuan berfikir dan daya ingat siswa bertambah. Siswa yang berada dalam sekolah menengah pertama memiliki usia yang tergolong remaja awal sehingga sifat penolakan terhadap sesuatu cenderung lebih besar. Penerimaan pengalaman belajar yang tidak sesuai akan menambah kemunduran kecerdasan kognitif setiap siswa. Sehingga dalam usia ini, guru atau pendidik harus dapat mendorong kemampuan berfikir siswa dengan memberikan rangsangan berupa hal-hal yang menarik contohnya media dalam bentuk science comic.( Hastuti, et al.,2014)

Respon terhadap bahan bacaan berbentuk komik ditunjukkan dengan ekspresi para siswa yang senang dengan isi cerita yang terdapat dalam komik dan rasa penasaran yang tinggi terhadap kelanjutan alur cerita yang ada pada komik. Hal ini sejalan dengan hasil wawancara tertulis dalam penelitian ini yaitu sebagian besar siswa sangat tertarik terhadap bahan baca berbentuk science comic dan pembelajaran sistem peredaran darah dianggap lebih efektif dan menarik menggunakan buku ajar dengan cerita bergambar daripada buku ajar yang biasa diterapkan oleh guru disekolah.

\section{SIMPULAN}

Berdasarkan hasil penelitian terdapat pengaruh science comic terhadap hasil belajar siswa pada materi sistem peredaran darah manusia. Hal ini ditunjukkan dengan hasil uji non- parametrik uji Wilcoxon sebesar 0,00 lebih kecil dari 0,05 sehingga hipotesis kerja (H1) dapat diterima. Perbedaan hasil rata-rata nilai posttest antara kelas eksperimen lebih tinggi dengan diberi perlakuan berupa penggunaan science comic dibanding dengan kelas kontrol tanpa penggunaan science comic atau dengan pembelajaran konstektual. Hasil rata-rata nilai posttest kelas eksperimen menunjukkan angka sebesar 85,37 dari 37 siswa sedangkan pada kelas kontrol sebesar 69 dari 35 siswa. Hasil nilai $N$-gain pada kelas eksperimen rata-rata yakni 0,77 dari 37 siswa dan pada kelas kontrol yakni 0,69 dari 35 siswa. Hasil $N$-gain yang lebih tinggi pada kelas eksperimen juga menunjukkan bahwa pembelajaran dengan menggunakan science comic berpengaruh terhadap hasil belajar siswa kelas VIII pada materi sistem peredaran darah manusia di SMP Negeri 7 Jember tahun ajaran 2017/2018.

\section{DAFTAR PUSTAKA}

Emda, A. (2011). Pemanfaatan Media Dalam Pembelajaran Biologi di Sekolah. Jurnal Ilmiah Didaktika, 12 (1)

Daryanto, (2015). Media Pembelajaran. Bandung: PT Sarana Tutorial Nurani Sejahtera.

Hastuti, A.A, Dewi, M \& Arif, W. (2014). Pengembangan LKS Berbasis Education Game Pada Tema Rokok dan Kesehatan. Jurnal Unnes Science Education, 3 (3) 
Kinasih, Y.F. (2011). Pengaruh Pendekatan Contextual Theaching and Learning Terhadap Hasil Belajar Biologi Pada KonsepStruktur dan Fungsi Tubuh Tumbuhan (Skripsi). Universitas Islam Negeri Syarif Hidayatullah Jakarta.

Nisa, K. (2014). Pengaruh Penggunaan Media Animasi Dengan Analogi Terhadap Hasil Belajar Biologi Siswa Pada Konsep Sistem Peredaran Darah (Skripsi). Universitas Islam Negeri Syarif Hidayatullah Jakarta.

Purnama, U.B, Mulyanto, \& Deni, T. (2015). Penggunaan Media Komik Digital dan Gambar Pengaruhnya Terhadap Prestasi Belajar IPA Ditinjau Dari Minat Belajar Siswa. Jurnal Teknodika, 13(2)

Rohman, A. (2015). Perbandingan Konsep Kurikulum Tingkat Satuan Pendidikan (KTSP) dan Kurikulum 2013 (Kajian Standar Isi Pada Mata Pelajaran Pendidikan Agama Islam Jenjang SMP) (Tesis). Universitas Islam Negeri Walisongo Semarang.

Silalahi, D.W. (2015). Penggunaan Media Komik Dalam pembelajaran Biologi Untuk Meningkat Hasil Belajar Kognitif dan afektif siswa kela VII. Prosiding Seminar Nasional Biologi Universitas Muhammadiyah Malang.

Sudjana ,N, \& Rivai. (2015). Media pengajaran. Bandung: Sinar Baru Algensindo.

Sujarweni, V.W. (2015). SPSS Untuk Penelitian. Yogyakarta: Pustaka Baru Press. Sugiyono. (2016). Metode Penelitian dan Pengembangan. Bandung: Alfabeta.

Suharso, P. (2012). Metode Penelitian Kuantitatif Untuk Bisnis. Jakarta: Permata Puri Media.

Wahab, A. (2016). Pengembangan Bahan Ajar Komik Pada Materi Sistem Transportasi Makhluk Hidup untuk Menumbuhkan Minat Baca danMeningkatkan Hasil Belajar. Jurnal Pendidikan Sains Pascasarjana Universitas Negeri Surabaya, 6 (1)

Zain, N.H. (2013). Pengembangan Komik Bahan Ajar IPA Terpadu Kelas VIII SMP Pada Tema Sistem Pencernaan Manusia dan Hubungannya dengan Kesehatan (Skripsi). Universitas Negeri Semarang.

Zaini, H. (2015). Karakteristik Kurikulum 2013 dan Kurikulum Tingkat Satuan Pendidikan (KTSP). Jurnal Idaroh, 1 (1): 15-31. 